\title{
Oligomeric Amyloid Decreases Basal Levels of Brain-Derived Neurotrophic factor (BDNF) mRNA via Specific Downregulation of BDNF Transcripts IV and V in Differentiated Human Neuroblastoma Cells
}

\author{
Diego J. Garzon and Margaret Fahnestock \\ Department of Psychiatry and Behavioural Neurosciences, McMaster University, Hamilton, Ontario, Canada L8N 3Z5
}

\begin{abstract}
Alzheimer's disease (AD) is a senile dementia characterized by amyloid plaques, neurofibrillary tangles, and synaptic and cell loss. The "amyloid cascade" hypothesis suggests that amyloid- $\beta(\mathrm{A} \beta)$, the peptide deposited as amyloid plaques, is the primary insult in AD. However, debate continues over the mechanism of $\mathrm{A} \beta$ toxicity and whether fibrillar or oligomeric $\mathrm{A} \beta$ is the active species of the peptide that ultimately causes the synaptic loss and dementia associated with AD. Brain-derived neurotrophic factor (BDNF) is required for survival and function of cells compromised in AD. Decreased BDNF causes defects in long-term potentiation and memory and correlates with cognitive decline. We previously demonstrated that BDNF reduction occurs early in the course of AD, suggesting that decreased BDNF may promote neuronal dysfunction in AD. We also demonstrated that three of seven human BDNF transcripts are specifically downregulated in $\mathrm{AD}$. What pathological feature(s) of AD leads to the decreased BDNF is unknown.

In this study, we administered both fibrillar and oligomeric conformations of A $\beta_{1-42}$ to differentiated SH-SY5Y, a human neuroblastoma cell line, and measured both phosphorylated cAMP response element-binding protein (CREB), a regulator of BDNF transcription, and BDNF total mRNA. We found that oligomeric but not fibrillar preparations of $\mathrm{A} \beta_{1-42}$ significantly decrease both phosphorylated CREB and total BDNF mRNA. Furthermore, oligomeric $\mathrm{A} \beta_{1-42}$ decreases BDNF transcripts IV and $\mathrm{V}$ in these cells, demonstrating that $\mathrm{A} \beta_{1-42}$ downregulates the major BDNF transcript decreased in vivo in the $\mathrm{AD}$ brain. Thus, oligomeric $\mathrm{A} \beta_{1-42}$ could compromise neuronal function, causing memory loss and cognitive dysfunction by downregulation of BDNF in AD.
\end{abstract}

Key words: Alzheimer; neurotrophin; exons; real-time RT-PCR; cell culture; CREB

\section{Introduction}

Alzheimer's disease $(\mathrm{AD})$ is marked by progressive decline in cognitive functions and distinct pathology including senile plaques, neurofibrillary tangles, and synaptic degeneration (Glenner and Wong, 1984; Grundke-Iqbal et al., 1986; Geula, 1998; Coleman and Yao, 2003). The amyloid cascade hypothesis identifies amyloid- $\beta(\mathrm{A} \beta)$ as the precipitating insult in $\mathrm{AD}$ (Selkoe, 1994), although how A $\beta$ produces synaptic degeneration is uncertain. Although fibrillar amyloid deposited as plaques may contribute to $\mathrm{AD}$ pathogenesis, oligomeric amyloid is now recognized as the major toxic species (Lambert et al., 1998) and correlates with neurodegeneration in AD (Lue et al., 1999; McLean et al., 1999; Gong et al., 2003).

Brain-derived neurotrophic factor (BDNF) has an established

Received May 16, 2006; revised Jan. 26, 2007; accepted Feb. 2, 2007.

This work was supported by grants from the Canadian Institutes for Health Research and the Scottish Rite Charitable Foundation of Canada (M.F.). D.J.G. is supported by studentships from the Alzheimer Society of Canada and the Scottish Rite Charitable Foundation of Canada. We thank Dr. Charlie Goldsmith for his advice on statistical analysis and Dr. Jane Foster for her advice on real-time PCR.

Correspondence should be addressed to Dr. Margaret Fahnestock, Department of Psychiatry and Behavioural Neurosciences, McMaster University, 1200 Main Street West, Hamilton, Ontario, Canada L8N 375. E-mail: fahnest@mcmaster.ca.

DOI:10.1523/JNEUROSCI.5053-06.2007

Copyright $\odot 2007$ Society for Neuroscience $\quad$ 0270-6474/07/272628-08\$15.00/0 role in neuronal survival (Yuan and Yankner, 2000) and in longterm potentiation (LTP), a form of synaptic plasticity associated with memory formation and consolidation (McAllister et al., 1999; Lu, 2003; Bramham and Messaoudi, 2005). Transgenic mice with reduced BDNF levels exhibit defects in synaptic transmission, LTP, and memory tests that are rescued by exogenous BDNF administration (Korte et al., 1995; Patterson et al., 1996; Olofsdotter et al., 2000). BDNF mRNA and protein are significantly decreased in $\mathrm{AD}$ and mildly cognitive impaired (MCI) subjects compared with controls (Phillips et al., 1991; Connor et al., 1997; Ferrer et al., 1999; Hock et al., 2000; Holsinger et al., 2000). Moreover, the decrease in BDNF correlates with the severity of cognitive impairment (Peng et al., 2005), identifying BDNF downregulation as an early and possibly underlying event in AD. In rodents, 42 aa amyloid- $\beta\left(\mathrm{A} \beta_{1-42}\right)$ compromises BDNF production and signaling (Tong et al., 2001, 2004; Wu et al., 2006). Although BDNF downregulation by $\mathrm{A} \beta_{1-42}$ has been demonstrated in rodent models, there have been no investigations of human $\mathrm{BDNF}$ regulation by $\mathrm{A} \beta_{1-42}$.

To investigate the effects of $A \beta_{1-42}$ on human BDNF expression, we used the retinoic acid (RA) differentiated human neuroblastoma cell line SH-SY5Y (SY5Y). Differentiated SY5Y cells express BDNF and TrkB, the high-affinity BDNF receptor, and 
Table 1. PCR primer sequences for human BDNF transcripts

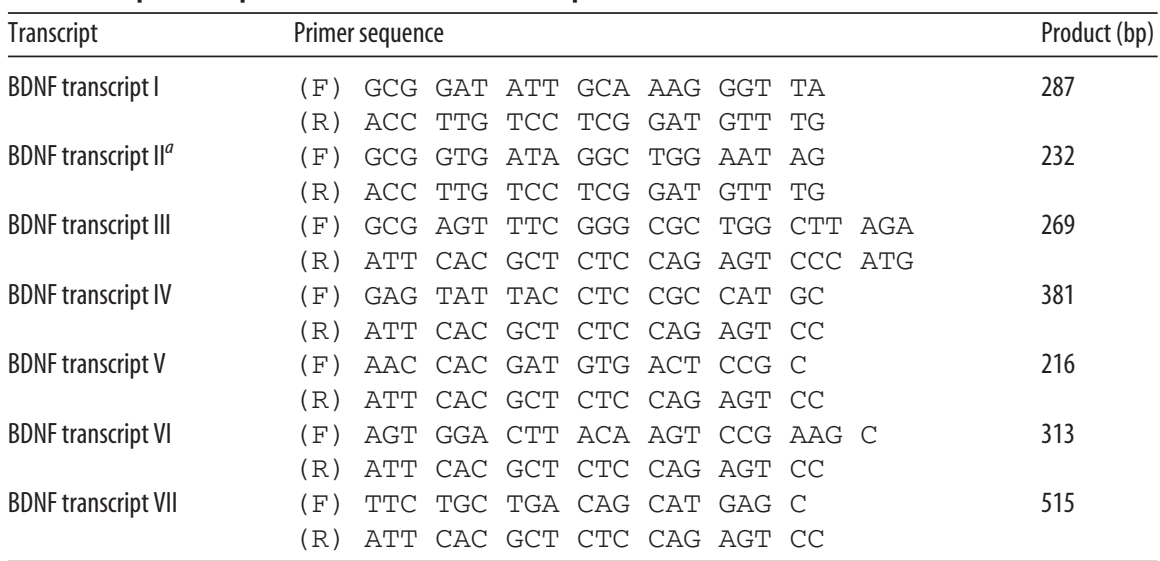

\section{$F$, Forward primer; $R$, reverse primer}

${ }^{a}$ Primers for BDNF transcript II encompass two of the three splice variants reported by Liu et al. (2005). We redesigned new primers to detect all three splice variants using the new forward sequence CAT TCA GCA CCT TGG ACA GA and the same reverse sequence from Table 1. PCR analysis with the new primers revealed splice variant 2 continued to be the most predominantly expressed transcript, and we were unable to detect the third splice variant in SH-SY5Y cells.

become dependent on BDNF for survival (Kaplan et al., 1993; Encinas et al., 2000; Feng et al., 2001). Furthermore, differentiated SY5Y cells develop a neuronal appearance, with long cell processes and expression of neuron-specific markers (Pahlman et al., 1984, 1990; Encinas et al., 2000) and, like human cortical neurons, are sensitive to A $\beta$ (Lambert et al., 1994; Datki et al., 2004; Deshpande et al., 2006).

The human BDNF gene consists of seven upstream noncoding exons differentially spliced to the downstream coding exon, producing multiple transcripts (Aoyama et al., 2001; Garzon et al., 2002; Liu et al., 2005) (see Fig. 1A). Upstream of the noncoding exons are promoters governing differential mechanisms of activation and tissue-specific transcript expression in the CNS (Ohara et al., 1992; Metsis et al., 1993; Kokaia et al., 1994; Timmusk et al., 1995). In AD, BDNF transcripts I, II, and IV are specifically decreased (Garzon et al., 2002). However, the mechanism responsible for the observed decrease in these BDNF transcripts is unknown. The aim of this study was to determine whether fibrillar or oligomeric $\mathrm{A} \beta_{1-42}$ downregulates BDNF, and if so, whether it downregulates the transcripts that are decreased in cortical tissue of subjects with AD.

\section{Materials and Methods}

SH-SY5Y cells. SH-SY5Y cells were a generous gift from Dr. L. T. Young (Centre for Addiction and Mental Health, Toronto, Ontario, Canada). Cells were incubated in DMEM (Invitrogen, Carlsbad, CA) with 10\% fetal bovine serum (FBS) (Invitrogen), 2 mm L-glutamine (L-Gln) (Invitrogen), and $1 \%$ penicillin/streptomycin (Pen/Strep) (Invitrogen). Cells were kept at $37^{\circ} \mathrm{C}$ and $5 \% \mathrm{CO}_{2}$ and split $1: 5$ every $5 \mathrm{~d}$. For cell differentiation, $3.25 \times 10^{5}$ cells per well were seeded in six-well plates (Sarstedt, Montreal, Quebec, Canada) in DMEM, 10\% FBS, 2 mM L-Gln, and $1 \% \mathrm{Pen} / \mathrm{Strep}$ for $24 \mathrm{~h}$, after which medium was replaced with DMEM, 1\% N-2 supplements (Invitrogen), 2 mM L-Gln, 1\% Pen/Strep, and $10 \mu \mathrm{m}$ all-trans RA (Sigma, St. Louis, MO). One-half of the medium was replaced every other day for $9 \mathrm{~d}$. After $9 \mathrm{~d}$ of RA differentiation, $5 \mu \mathrm{M}$ $\mathrm{A} \beta_{1-42}$ was added in fresh medium and incubated for $48 \mathrm{~h}$.

Amyloid preparation. Amyloid- $\beta$ was purchased from American Peptide Company (Sunnyvale, CA) or rPeptide (Athens, GA). For initial

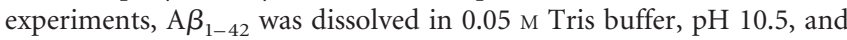
either $\mathrm{A} \beta_{1-42}$ or vehicle was added to fresh medium (DMEM, $1 \% \mathrm{~N}-2$ Supplements, $2 \mathrm{~mm} \mathrm{~L}-\mathrm{Gln}, 1 \%$ Pen/Strep, and $10 \mu \mathrm{m}$ all-trans RA) to a final concentration of $5 \mu \mathrm{M}$.

Preparation of fibrillar or oligomeric amyloid was from Dahlgren et al. (2002). Briefly, both $A \beta_{1-42}$ and scrambled $A \beta_{1-42}$ (with the same amino acid composition as $\mathrm{A} \beta_{1-42}$ but in random sequence) (rPeptide) were dissolved to $1 \mathrm{~mm}$ in $100 \% 1,1,1,3,3,3$ hexafluoro-2-propanol (HFIP). HFIP was dried in the fume hood and resuspended to 5 mM in anhydrous DMSO. For fibril-forming conditions, amyloid or scrambled peptide was brought to a final concentration of $100 \mu \mathrm{M}$ with $10 \mathrm{~mm} \mathrm{HCl}$ and incubated for $24 \mathrm{~h}$ at $37^{\circ} \mathrm{C}$. For oligomer-forming conditions, amyloid or scrambled peptide was diluted to a final concentration of $100 \mu \mathrm{M}$ with Ham's F-12 (phenol red free; BioSource, Camarillo, CA) and incubated at $4^{\circ} \mathrm{C}$ for $24 \mathrm{~h}$. After incubation, fibrillar or oligomeric amyloid or vehicle was added to fresh medium (DMEM, N-2 supplements, L-Gln, Pen/Strep, and all-trans RA) and incubated with cells at $37^{\circ} \mathrm{C}$ for $48 \mathrm{~h}$. Amyloid administration was conducted in two independent experiments with three separate samples per group.

$R N A$ isolation, DNase treatment, reverse transcription, and absolute quantitative PCR. After $48 \mathrm{~h}$ incubation in the presence of $\mathrm{A} \beta_{1-42}$, scrambled peptide, or vehicle, cells were lysed with $1 \mathrm{ml}$ of Trizol (Invitrogen), and RNA was isolated with RNeasy Spin columns (Qiagen, Mississauga, Ontario, Canada). The procedure for RNA isolation with Trizol and RNeasy spin columns was followed as specified by Qiagen. RNA purity was confirmed by spectrophotometry $\left(A_{260} / A_{280}>1.7\right)$ and RNA integrity was visualized by agarose gel electrophoresis.

One microgram of RNA was treated with $2 \mathrm{U}$ of Turbo DNase (Ambion, Austin, TX). For reverse transcription (RT), the protocol and reagents for Superscript II of Invitrogen were used. The final volume of 20 $\mu \mathrm{l}$ contained $250 \mathrm{ng}$ of random primers, $0.5 \mathrm{~mm}$ dNTPs $(0.5 \mathrm{~mm}$ each of dATP, dTTP, dCTP, and dGTP), $1 \times$ first-strand buffer, 0.05 mM DTT, 2 $\mathrm{U}$ of RNaseOUT, and $200 \mathrm{U}$ of Superscript II (Moloney murine leukemia virus RT). As a control, $1 \mu \mathrm{g}$ of RNA was treated according to the same protocol with addition of water instead of the RT enzyme ("no RT" control).

Real-time PCR was performed in the Stratagene (La Jolla, CA) MX3000P using the DNA binding dye SYBR green (Platinum SYBR Green qPCR SuperMix UDG; Invitrogen). The $20 \mu \mathrm{l}$ PCR mix contained $1 \times \mathrm{qPCR}$ SuperMix, forward and reverse primers, $30 \mathrm{~nm}$ ROX reference dye (Stratagene), and cDNA from $50 \mathrm{ng}$ of RNA or reference standard for absolute quantification. A "no template" control lacking RNA was included. For BDNF detection, 300 nM forward and reverse primers were used (forward primer, 5' -AAA CAT CCG AGG ACA AGG TG; reverse primer, 5'-AGA AGA GGA GGC TCC AAA GG; product, 249 bp), and $150 \mathrm{~nm}$ forward and reverse primers were used for $\beta$-actin (forward primer, $5^{\prime}$-CTC TTC CAG CCT TCC TTC; reverse primer, $5^{\prime}$-TGT TGG CGT ACA GGT CTT; product, $109 \mathrm{bp}$ ). Levels of BDNF and $\beta$-actin were determined using absolute quantification. Standards for BDNF were made in our laboratory from a pGEM plasmid containing the entire BDNF coding region of 755 bp (National Center for Biotechnology Information accession no. AY890649) and were run in triplicate with six 10 -fold dilutions starting at $2.4 \times 10^{6}$ copies of pGEM plasmid. $\beta$-Actin standards were from a plasmid obtained from Invitrogen and were run in duplicate with six 10-fold dilutions starting at $1.0 \times 10^{7}$ copies of plasmid. Standards for individual BDNF transcripts were run in triplicate and obtained from purified PCR products using the primers listed in Table 1. Only experiments with $R^{2}>0.990$ and a PCR efficiency between 90 and $100 \%$ were used for analysis. All unknowns, no RT, and no template controls were run in triplicate. The following thermal profile was used for total BDNF and $\beta$-actin: $2 \mathrm{~min}$ at $50^{\circ} \mathrm{C}, 2 \mathrm{~min}$ at $95^{\circ} \mathrm{C}$ followed by 40 cycles of $95^{\circ} \mathrm{C}$ for $15 \mathrm{~s}, 58^{\circ} \mathrm{C}$ for $30 \mathrm{~s}$, and $72^{\circ} \mathrm{C}$ for $30 \mathrm{~s}$. For individual BDNF transcripts, the 40 cycles had the following thermal profile: $95^{\circ} \mathrm{C}$ for $30 \mathrm{~s}, 58^{\circ} \mathrm{C}$ for $30 \mathrm{~s}$, and $72^{\circ} \mathrm{C}$ for $45 \mathrm{~s}$. After PCR, a dissociation curve was added to verify that no secondary products had formed. Results were expressed as copies per nanogram of total RNA.

Western blotting. To confirm fibrillar and oligomeric speciation of 
$\mathrm{A} \beta_{1-42}$, Western blotting was performed following the protocols of Dahlgren et al. (2002) and Stine et al. (2003) with the following modifications: $\mathrm{A} \beta_{1-42}$ samples were diluted in $4 \times$ loading buffer $(0.25 \mathrm{M}$ Tris$\mathrm{HCl}, \mathrm{pH} 6.8,8 \%$ SDS, $40 \%$ glycerol, $20 \% \beta$-mercaptoethanol, $0.004 \%$ bromophenol blue) and separated by SDS-PAGE in a $12 \%$ Tris/glycine gel.

For determination of cAMP response element-binding protein (CREB), phosphorylated CREB (P-CREB), caspases-3 and -7 , and $\beta$-actin, RA-differentiated SY5Y cells subjected to different treatments were lysed in buffer containing $50 \mathrm{~mm}$ Tris, pH 7.4, 1\% NP-40, $0.25 \%$ sodium deoxycholate, $150 \mathrm{~mm} \mathrm{NaCl}, 1 \mathrm{~mm}$ EGTA, $\mathrm{pH}$ 8, 1 mm sodium orthovanadate, $1 \mathrm{~mm} \mathrm{NaF}, 1 \mathrm{~mm}$ PMSF, and $1 \mu \mathrm{g} / \mathrm{ml}$ each of aprotinin, leupeptin, and pepstatin A. Samples were centrifuged for 5 min at $300 \times$ $g$. Protein concentration of the supernatant was determined using a DC protein assay (Bio-Rad, Hercules, CA). Twenty micrograms of total protein in $4 \times$ loading buffer was separated by SDS-PAGE in a $12 \%$ Tris/ glycine gel.

After transfer to polyvinylidene fluoride membranes and blocking for $1 \mathrm{~h}$ at room temperature in $1 \times$ Tris buffered saline (TBS) $-0.1 \%$ Tween 20 (TBS/T) with 5\% nonfat dry milk (MLK) [or PBS containing 3\% nonfat dry milk (PBS-MLK) for CREB and P-CREB], blots were incubated overnight at $4^{\circ} \mathrm{C}$ with primary antibodies for $\mathrm{A} \beta_{1-42}$ (6E10; Signet Laboratories, Dedham, MA; diluted 1:3000 in TBS/T), $\beta$-actin (Sigma; diluted 1:5000 in TBS/T), caspases-3 and -7 (Cell Signaling Technology, Danvers, MA; diluted 1:1000 in TBS/T-MLK), or CREB and P-CREB (Upstate, Lake Placid, NY; diluted 1:1000 in PBS-MLK). Secondary antibodies anti-mouse IgG HRP (GE Healthcare, Buckinghamshire, UK) diluted 1:5000 for $\mathrm{A} \beta_{1-42}, 1: 5000$ for $\beta$-actin, and 1:2000 for caspase-7, or anti-rabbit IgG HRP (Cell Signaling) diluted 1:2000 for caspase-3 and 1:5000 for CREB and P-CREB, were incubated for $1 \mathrm{~h}$ at room temperature. Blots were developed using enhanced chemiluminescence (GE Healthcare) and visualized using CL-X Posure film (Pierce Biotechnology, Rockford, IL). Pixel density was determined using Scion Image software (Scion, Frederick, MD).

Cell viability assay. Amyloid-induced cytotoxicity was determined by measuring release of cytosolic lactate dehydrogenase (LDH) into the medium (Cytotox 96 nonradioactive cytotoxicity assay; Promega, Madison, WI). The protocol was followed as specified by the manufacturer. Each sample was tested in triplicate, and the LDH release was measured at $492 \mathrm{~nm}$ using a Titertek Multiscan Plus (MP Biomedicals, Irvine, CA) plate reader.

Quantitative and statistical analysis. Samples for BDNF mRNA exposed to different species of amyloid- $\beta$ and LDH cytotoxicity were assayed in triplicate in each of two independent experiments. Data from Western blots for total CREB (T-CREB), P-CREB, and caspases- 3 and -7 were obtained from three independent experiments. The data were analyzed by one-way ANOVA with post hoc Tukey's test for pairwise group comparison or Student's $t$ test where indicated (SPSS, version 13, software; SPSS, Chicago, IL).

\section{Results}

Retinoic acid-differentiated SH-SY5Y cells express all BDNF transcripts

RA-differentiated SY5Y cells after $9 \mathrm{~d}$ in vitro express all seven BDNF transcripts (Fig. 1B). The BDNF transcript expression pattern in SH-SY5Y cells is very similar to that of human cortical tissue. A comparison of levels of each BDNF transcript demonstrates that BDNF transcript IV is the most highly expressed transcript in both the human cortex and SY5Y cells, representing over one-half of the total BDNF (Table 2). Both the human cortex and SY5Y cells predominantly express BDNF transcripts I, IV, and V, whereas transcripts II, VI, and VII are minor contributors to the total, and transcript III is not detectable (Table 2).

\section{Retinoic acid induces BDNF mRNA expression}

BDNF mRNA levels increased significantly over time when cells were grown in serum free medium with $\mathrm{N}-2$ supplements and 10
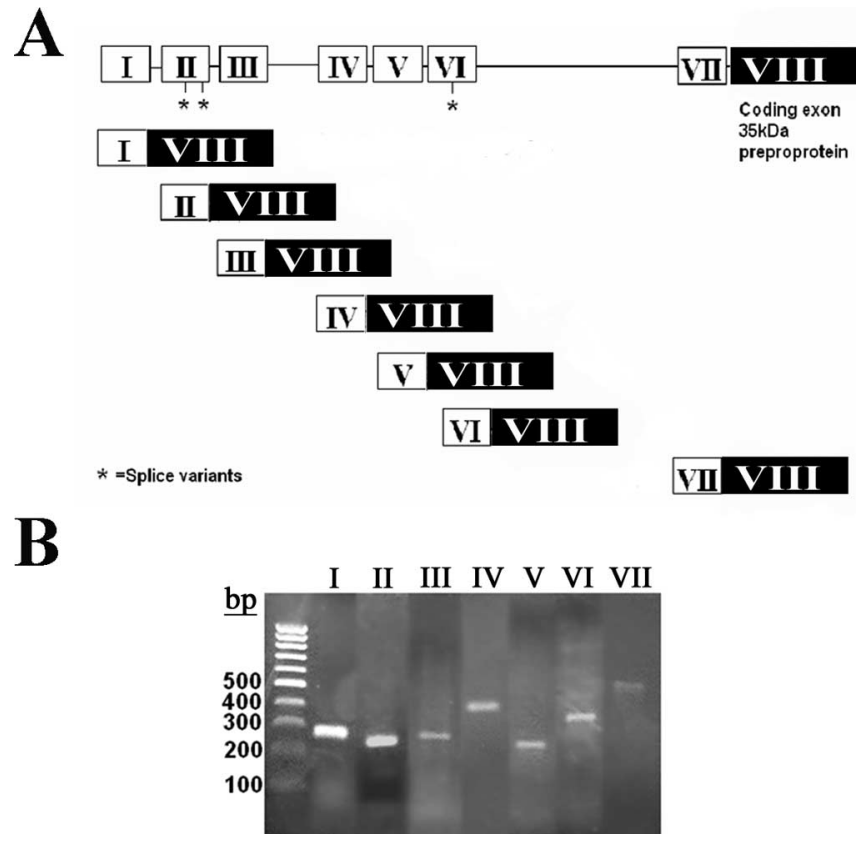

Figure 1. Human BDNF gene with mRNA transcripts. A, Diagram showing the entire BDNF gene with the noncoding exons in white spliced to the coding exon in black. The asterisk $\left(^{*}\right)$ indicates splice variants, of which three are known, two on exon II and one on exon VI for a total of 10 transcripts. $B, P C R$ products for all seven BDNF transcripts from retinoic acid-differentiated SH-SY5Y cells at 9 din vitro. Lanes numbered I-VII correspond to the transcripts in $A$. PCR primer sequences and size of fragments are found in Table 1. The splice variants, although present, are not significant products in lanes 2 and 6. A 100 bp ladder is shown on the left.

Table 2. BDNF transcript abundance in human parietal cortex and RAdifferentiated human neuroblastoma SH-SY5Y cells

\begin{tabular}{|c|c|c|c|}
\hline \multicolumn{2}{|l|}{ Human parietal cortex } & \multicolumn{2}{|c|}{ Human neuroblastoma SH-SY5Y } \\
\hline BDNF transcript order & Copies $^{a}$ & BDNF transcript order & Copies $^{b}$ \\
\hline Transcript IV & 625 & Transcript IV & 643 \\
\hline Transcript I & 332 & Transcript V & 215 \\
\hline Transcript V & 130 & Transcript I & 121 \\
\hline Transcript VI & 70 & Transcript II & 95 \\
\hline Transcript VII & 16 & Transcript VI & $\mathrm{N} / \mathrm{D}$ \\
\hline Transcript II & 15 & Transcript VII & $\mathrm{N} / \mathrm{D}$ \\
\hline Transcript III & $\mathrm{N} / \mathrm{D}$ & Transcript III & $\mathrm{N} / \mathrm{D}$ \\
\hline
\end{tabular}

${ }^{a}$ Determination of BDNF transcript copy number for human parietal cortex was done using relative quantitative RT-PCR with incorporation of ${ }^{33} \mathrm{P}$ (Garzon et al. 2002). The ${ }^{33} \mathrm{P}$ isotope was detected by pixelation intensity on a phosphorimage cassette, and pixel values were averaged for all control subjects for each BDNF transcript. One pixel was assigned a value of 65,000 and was used as the denominator in the following ratio: total averaged pixe value $/ 65,000$. The value of the ratio appears in the 'Copies' column (under 'Human parietal cortex'). BDNF transcript III was not detectable (N/D) in human parietal cortex.

${ }^{b}$ Determination of BDNF transcript copies after $9 \mathrm{~d}$ of retinoic acid differentiation of SH-SY5Y cells, using absolute quantitative real-time $P C R$. Three samples per group were assayed in triplicate in each of two independent experiments. The value of ' Copies' (under 'Human neuroblastoma SH-SY5Y') is copies of BDNF per $50 \mathrm{ng}$ of total input RNA. BDNF transcripts III, Vl, and VII were below quantifiable levels (N/D, $<40$ copies/50 ng total RNA).

$\mu \mathrm{M}$ RA (Fig. 2). BDNF mRNA was significantly increased at $3 \mathrm{~d}$ (one-way ANOVA and post hoc Tukey's test, $p<0.01$ ), $5 \mathrm{~d}$ ( $p<$ $0.001)$, and $9 \mathrm{~d}(p<0.001)$ of growth in N-2 and RA compared with serum free medium with $\mathrm{N}-2$ supplements alone or with medium with 10\% FBS (Fig. 2).

\section{$\mathrm{A} \boldsymbol{\beta}_{1-42}$ downregulates BDNF mRNA in human neuroblastoma SH-SY5Y cells} The effect of $5 \mu \mathrm{M} \mathrm{A} \beta_{1-42}$ administration on BDNF mRNA in SY5Y cells was examined after incubation for $6,12,24$, and $48 \mathrm{~h}$. Five micromolar $\mathrm{A} \beta_{1-42}$ is a concentration previously reported to interfere with cellular signaling without induction of apoptosis 


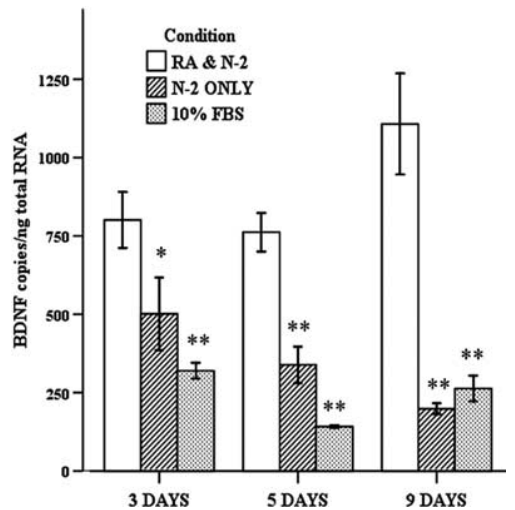

Figure 2. Measurement of total BDNF mRNA after 3,5, and $9 \mathrm{~d}$ of growth in different media. BDNF is significantly increased in $\mathrm{N}-2$ supplements and $10 \mu \mathrm{M}$ RA compared with $\mathrm{N}-2$ supplements alone or $10 \% \mathrm{FBS}$ at 3,5 , and $9 \mathrm{~d}\left({ }^{*} p<0.01 ; * * 0.001\right)$. In addition, comparing BDNF $m R N A$ levels for $\mathrm{N}-2$ and RA across the time points, there is a significant increase in BDNF mRNA between days 3 and $9\left({ }^{*} p=0.036\right)$ and between days 5 and $9\left({ }^{*} p=0.022\right)$. Error bars represent SEM; $n=3$.
(Tong et al., 2001, 2004). Although total BDNF mRNA (exon VIII) was decreased at all time points, the greatest decrease occurred at $48 \mathrm{~h}$ (data not shown). The $48 \mathrm{~h}$ time point was subsequently used for all additional experiments. Administration of $5 \mu \mathrm{M} \mathrm{A} \beta_{1-42}$ for $48 \mathrm{~h}$ to SY5Y cells resulted in a $33 \%$ decrease in total BDNF mRNA compared with vehicle-treated cells (Student's $t$ test, $p=0.002$ ). In contrast, amyloid- $\beta$ did not downregulate BDNF in undifferentiated SY5Y cells (data not shown).

\section{$A \beta_{1-42}(5 \mu \mathrm{M})$ in fibrillar or oligomeric conformations is not cytotoxic to $\mathrm{SH}-\mathrm{SY} 5 \mathrm{Y}$ cells}

To confirm that $\mathrm{A} \beta_{1-42}$ is not cytotoxic to SY5Y cells under these conditions, a colorimetric assay measuring the release of cytoplasmic LDH and Western blots measuring levels of caspases-3 and -7 were used. There was no change in levels of inactivated caspases- 3 and -7 or in LDH release from cultures exposed to fibrillar or oligomeric $\mathrm{A} \beta_{1-42}$ for $48 \mathrm{~h}$ in comparison with the scrambled peptide or no peptide controls (one-way ANOVA, $p>$ 0.05) (Fig. 3, Table 3).

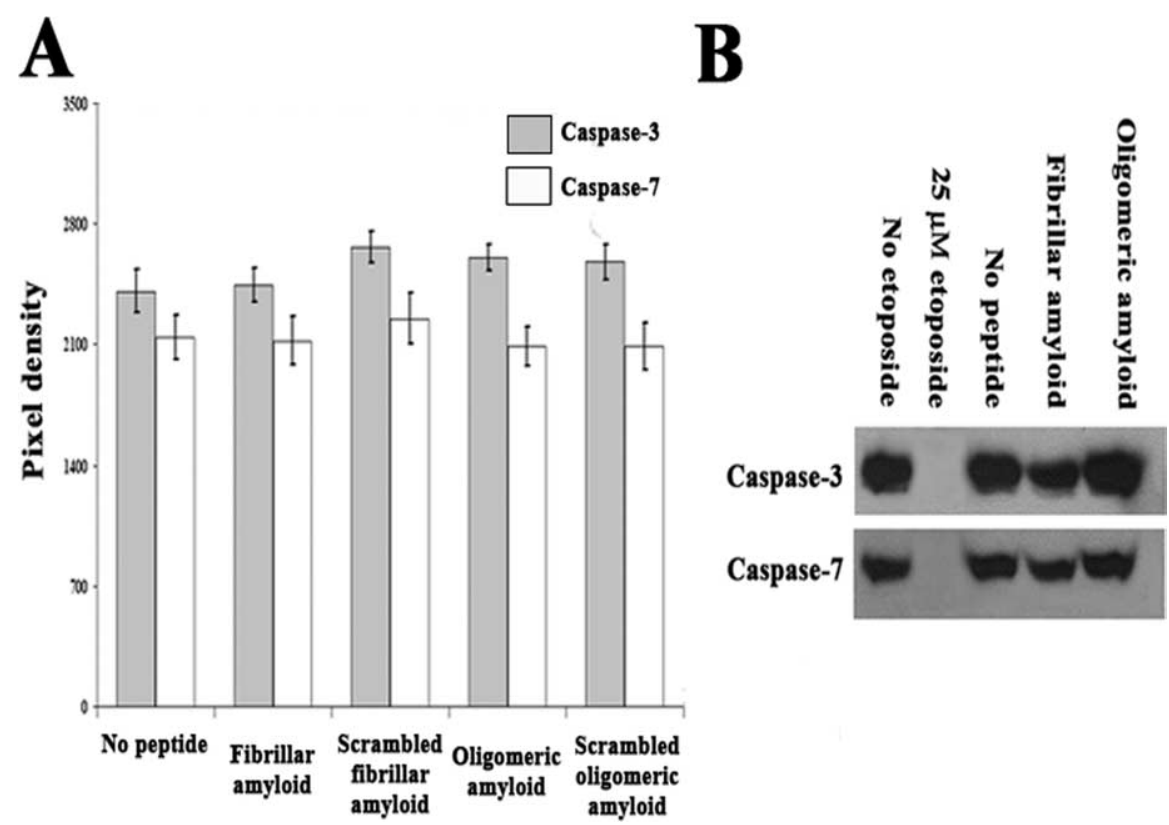

Figure 3. Western blotting of inactivated caspase- 3 and -7 . A, No difference in levels of inactivated caspase- 3 and -7 among differently treated RA-differentiated SY5Y cells (one-way ANOVA, $p=0.354$ for caspase-3, and $p=0.921$ for caspase-7). Analysis is based on three independent experiments; $n=9$. Error bars represent SEM. $\boldsymbol{B}$, Western blot shows only inactivated caspase-3 and -7 were detected after treatment with $A \beta_{1-42}$. As a positive control, SY5Y cells were treated with $25 \mu \mathrm{m}$ etoposide, an apoptosis-inducing reagent. After $24 \mathrm{~h}$, no inactivated caspase- 3 or -7 was detected.

Table 3. Percentage cytotoxicity after $48 \mathrm{~h} 5 \mu \mathrm{M} \mathrm{A} \beta_{1-42}$ administration, determined by LDH assay

\begin{tabular}{ll}
\hline Condition & Percentage cytotoxicity $^{a}$ \\
\hline Control (no peptide) & 17.82 \\
Fibrillar $A \beta_{1-42}$ & 11.77 \\
Scrambled fibrillar $A \beta_{1-42}$ & 17.92 \\
Oligomeric $A \beta_{1-42}$ & 17.36 \\
Scrambled oligomeric $A \beta_{1-42}$ & 17.17 \\
\hline
\end{tabular}

${ }^{a}$ One-way ANOVA, $p=0.84$.
Oligomeric but not fibrillar $A \boldsymbol{\beta}_{1-42}$ significantly decreases BDNF mRNA The $5 \mu \mathrm{M} \mathrm{A} \beta_{1-42}$ applied for $48 \mathrm{~h}$ was an undefined, heterogeneous mixture of fibrillar and oligomeric amyloid. To determine which amyloid species was responsible for BDNF downregulation, homogeneous fibrillar and oligomeric amyloid samples were prepared. Western blotting with an antibody to $A \beta$ confirmed the efficacy of the $A \beta_{1-42}$ oligomeric and fibrillar speciation procedure (Fig. 4). The oligomeric preparation (lane 1) contained monomers $(4 \mathrm{kDa})$, small oligomeric trimers $(\sim 12 \mathrm{kDa})$, and the larger oligomeric amyloid (40-98 kDa), but no fibrils. The fibrillar amyloid (lane 2) contained both monomeric amyloid and fibrillar amyloid $(>250 \mathrm{kDa})$, but no detectable oligomers. The procedures for amyloid speciation were also performed on the scrambled peptide, containing the same amino acid composition as $\mathrm{A} \beta_{1-42}$, which served as a negative control and did not cross-react with the amyloid antibody (lanes 3 and 4). After confirmation of the amyloid species, oligomeric or fibrillar $A \beta_{1-42}$ was added to the SY5Y cells. Scrambled A $\beta_{1-42}$ treated identically to oligomeric and fibrillar preparations and vehicle without added peptide served as negative controls. Total BDNF mRNA was decreased 62\% (ANOVA and post hoc Tukey's test, $p<0.001)$ in cultures exposed to oligomeric preparations of $\mathrm{A} \beta_{1-42}$ compared with scrambled oligomeric peptide and control without peptide (Fig. 5). SY5Y cells treated with fibrillar and oligomeric scrambled peptide controls showed no change in BDNF levels compared with controls without added peptide $(p>0.05)$ (Fig. 5). Furthermore, cells treated with fibrillar $\mathrm{A} \beta_{1-42}$ showed no change in BDNF levels compared with scrambled controls or controls without added peptide $(p>$ 0.05) (Fig. 5). 


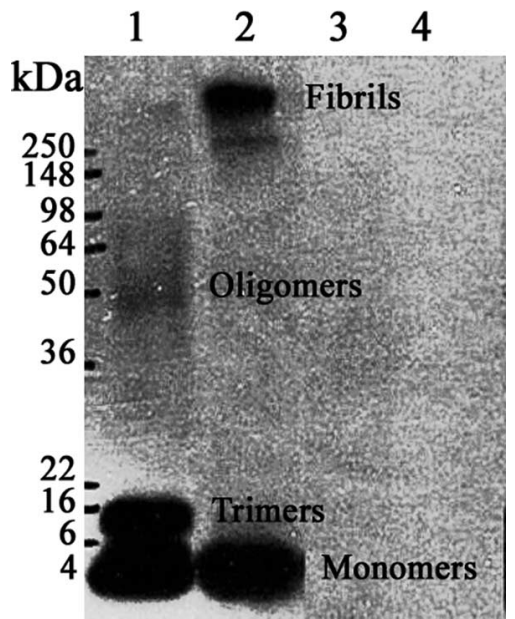

Figure 4. Western blot of fibrillar and oligomeric $A \beta_{1-42}$ speciation. The oligomeric preparation (lane 1$)$ contains monomers $(4 \mathrm{kDa})$, small oligomeric trimers $(\sim 12 \mathrm{kDa})$, and the larger oligomeric amyloid (40-98 kDa), but no fibrils. The fibrillar amyloid (lane 2) contains both monomeric amyloid and fibrillar amyloid ( $>250 \mathrm{kDa}$ ), but no oligomers. The procedures for amyloid speciation were also performed on the scrambled peptide, containing the same amino acid composition as $A \beta_{1-42}$, which served as a negative control and did not cross-react with the amyloid antibody (lanes 3 and 4).

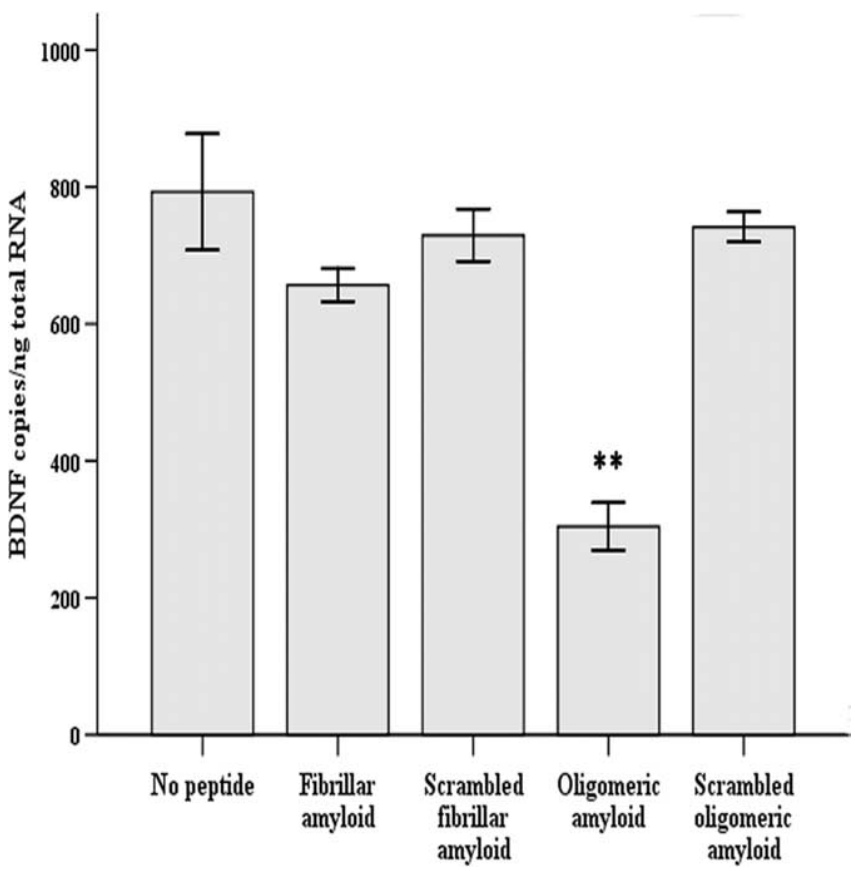

Figure 5. BDNF mRNA levels in RA-differentiated SY5Y cells exposed to oligomeric or fibrillar $A \beta$. Five micromolar $A \beta_{1-42}$, treated to form either oligomeric or fibrillar species, was added to RA-differentiated SH-SY5Y cells for $48 \mathrm{~h}$. Only oligomeric amyloid caused a significant decrease $\left({ }^{* *} p<0.001\right)$ in BDNF mRNA (exon VIII) compared with no peptide and scrambled oligomeric amyloid controls. There was no change in BDNF exposed to fibrillar amyloid compared with either no peptide or scrambled fibril controls. The analysis is based on two independent experiments; $n=6$. Error bars represent SEM.

\section{Oligomeric $A \boldsymbol{\beta}_{1-42}$ decreases BDNF transcripts 4 and 5}

Examination of the levels of each of the seven BDNF transcripts demonstrated oligomeric $\mathrm{A} \beta_{1-42}$ decreased BDNF transcripts IV and $\mathrm{V}$ by $45 \%$ (ANOVA and post hoc Tukey's test, $p=0.001$ ) and $54 \%(p=0.015)$, respectively (Fig. $6 C, D)$, increased BDNF transcript I by $70 \%(p=0.034)$ (Fig. $6 A)$, and did not change BDNF transcript II levels (Fig. 6B). BDNF transcripts III, VI, and VII were below the level of the standard curve both before and after $\mathrm{A} \beta_{1-42}$ administration ( $<40$ copies/50 ng total RNA).

\section{Oligomeric but not fibrillar $\mathbf{A} \boldsymbol{\beta}_{1-42}$ significantly decreases levels of phosphorylated CREB}

Levels of phosphorylated CREB were decreased by 38\% in samples treated with oligomeric amyloid compared with all other groups (one-way ANOVA and post hoc Tukey's test, $p=0.005$ ) (Fig. 7). The levels of total CREB protein did not differ among amyloid and control groups (one-way ANOVA, $p>0.05$ ) (Fig. 7).

\section{Discussion}

In this study, we showed that $A \beta_{1-42}$ significantly decreases BDNF mRNA and P-CREB, a transcriptional regulator of BDNF. We demonstrated that oligomeric, not fibrillar, species of $A \beta_{1-42}$ are responsible for the observed effects. Furthermore, oligomeric $\mathrm{A} \beta_{1-42}$ significantly decreases BDNF transcripts IV and V. Transcript IV is the most abundantly expressed BDNF transcript in human cortical tissue and in SY5Y cells and is decreased in $\mathrm{AD}$ (Garzon et al., 2002). Therefore, our results suggest that $\mathrm{A} \beta_{1-42}$ is responsible for the majority of BDNF downregulation in $\mathrm{AD}$.

RA-differentiated SY5Y cells demonstrate human neuronal characteristics, making their use as a model system ideal. They exhibit neuronal morphology and express neuron-specific markers including neurofilaments, neuron-specific enolase, and growth-associated protein- 43 as well as the neuronal polarity markers tau and microtubule-associated protein 2 (Pahlman et al., 1984, 1990; Encinas et al., 2000). We show that, unlike previously reported human and murine cell culture systems, RAdifferentiated SY5Y cells produce endogenous BDNF, increasing BDNF expression over the course of RA administration. A previous study in rat demonstrated that membrane depolarizationinduced BDNF upregulation is disrupted by $\mathrm{A} \beta_{1-42}$ administration (Tong et al., 2001). Our findings are the first to report that $\mathrm{A} \beta$ administration significantly decreases basal levels of BDNF mRNA and to identify oligomeric amyloid as responsible for the observed decrease.

In addition, we report here that the expression of BDNF transcripts in RA-differentiated SY5Y cells correlates closely with the expression pattern of BDNF transcripts in postmitotic human CNS tissue. Furthermore, RA-differentiated SY5Y cells closely resemble human cortical neurons in their response to $A \beta$ (Deshpande et al., 2006). Primary murine neuronal cultures were not used in this study, because the number and the expression patterns of BDNF transcripts in the brain differ between human and mouse (Garzon et al., 2002; Liu et al., 2005, 2006).

The amyloid cascade hypothesis proposes that $\mathrm{A} \beta$ production and toxic action on neurons and tissues cause AD. SY5Y cells have been used extensively to study mechanisms of $A \beta$ toxicity. $A \beta$ binds to the neurites of differentiated SY5Y cells, promoting neurite degeneration and induction of tau hyperphosphorylation (Datki et al., 2004). Similar data are reported for rat and human cultured neurons (Gong et al., 2003; Lacor et al., 2004; Deshpande et al., 2006).

Acceptance of the original amyloid cascade hypothesis is not pervasive, because data support no correlation between plaque deposition and neurodegeneration (Cummings and Cotman, 1995; Irizarry et al., 1997; Chui et al., 1999; Naslund et al., 2000). However, oligomeric $\mathrm{A} \beta_{1-42}$ is a potent neurotoxin at nanomolar concentrations and inhibits LTP and synaptic plasticity (Lambert et al., 1998; Walsh et al., 2002). Oligomeric $\mathrm{A} \beta_{1-42}$ levels are increased in areas of the brain compromised in $\mathrm{AD}$ and are correlated with areas of neurodegeneration; oligomeric $\mathrm{A} \beta_{1-42}$ is 

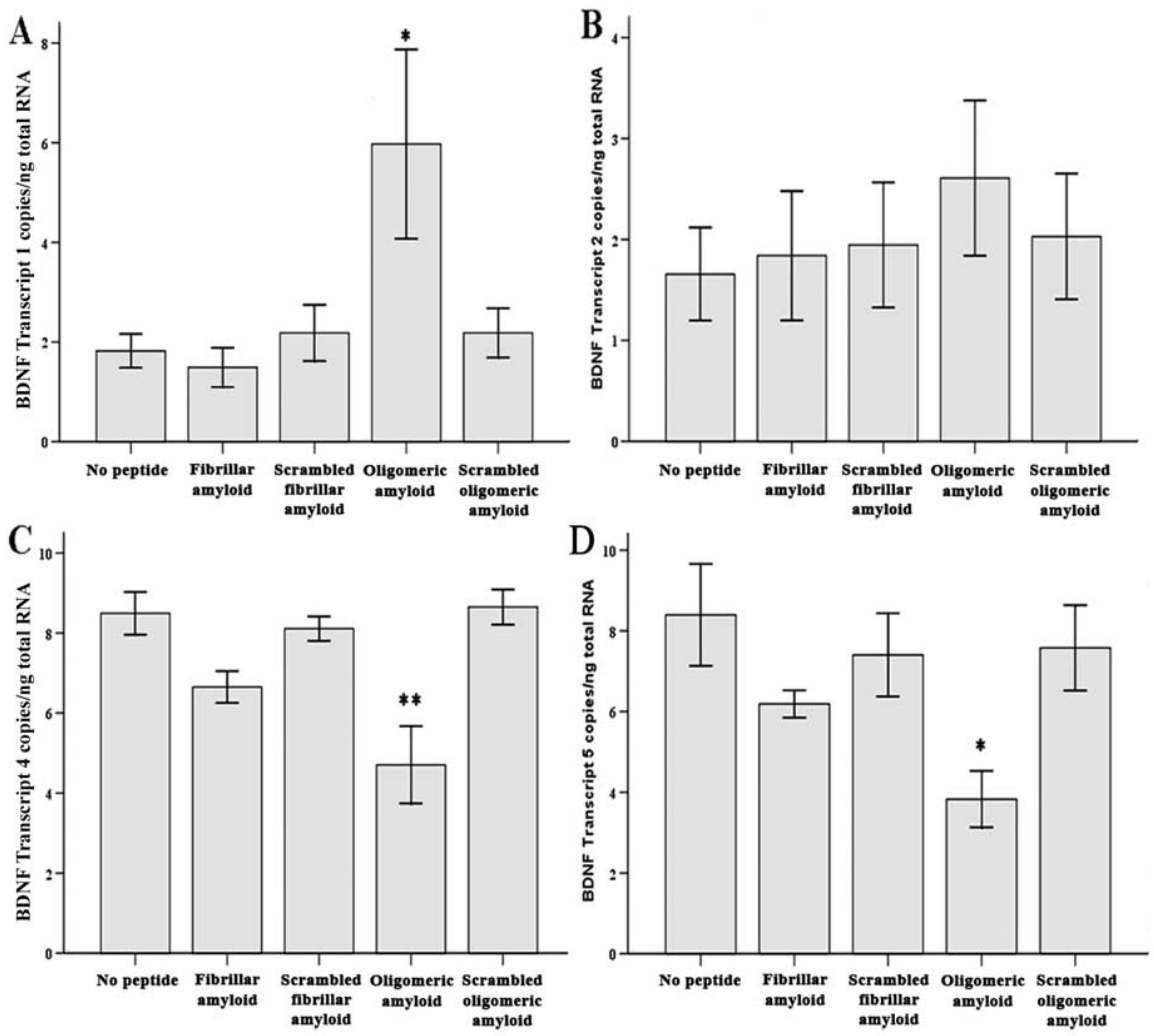

Figure 6. Measurement of BDNF transcripts I, II, IV, and V in RA-differentiated SY5Y cells exposed to oligomeric or fibrillar A $\beta$. $A, A$ significant increase $\left({ }^{*} p=0.034\right)$ in BDNF transcript I after oligomeric amyloid administration compared with both control conditions. $\boldsymbol{B}$, No change in BDNF transcript II levels among the five experimental conditions. C, D, Significant decreases in BDNF transcripts IV and V $\left({ }^{* *} p=0.001\right.$ and ${ }^{*} p=0.015$, respectively) after oligomeric amyloid administration compared with both controls. There was no change in any BDNF transcript level after fibrillar amyloid administration compared with either control. Transcripts III, VI, and VII were below the levels of detection. The analysis is based on two independent experiments; $n=6$. Error bars represent SEM.

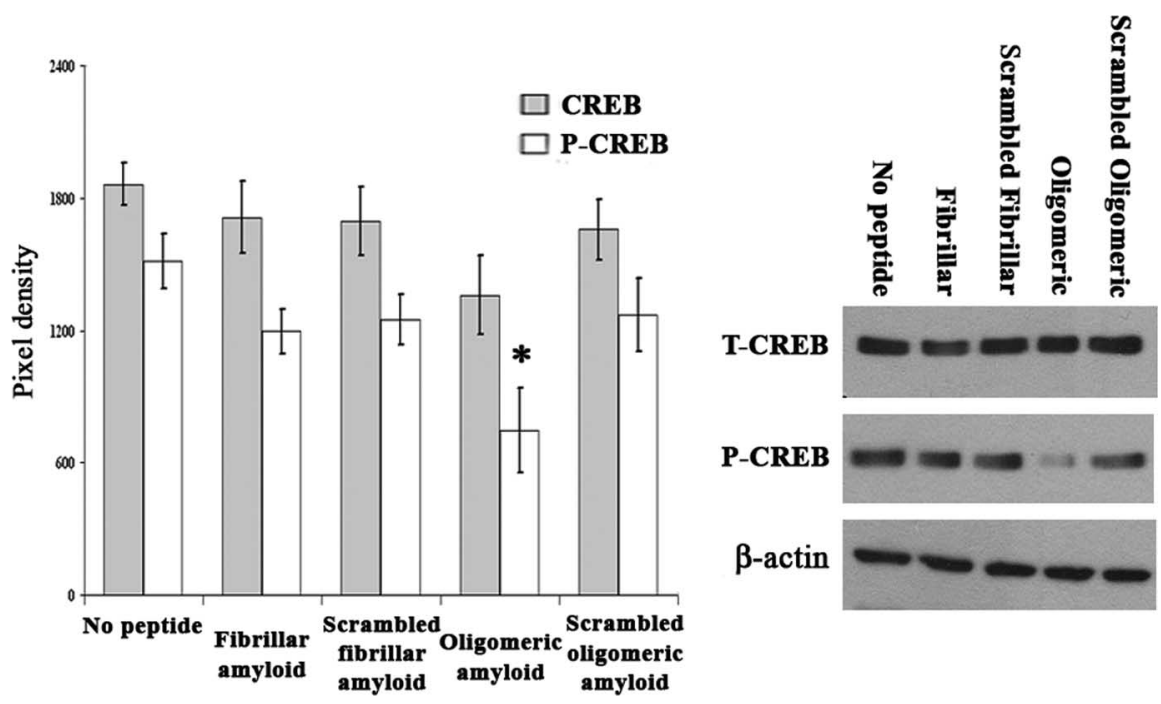

Figure 7. Western blots of T-CREB and P-CREB levels in RA-differentiated SY5Y cells treated with oligomeric or fibrillar A $\beta$. RA-differentiated SY5Y cells administered oligomeric amyloid demonstrate significantly decreased phosphorylated CREB levels $\left({ }^{*} p=0.005\right)$. Levels of total CREB were unchanged among all five conditions (one-way ANOVA, $p=0.237$ ). The analysis is based on three independent experiments; $n=9$. Error bars represent SEM.

more neurotoxic than fibrillar amyloid and is found intracellularly, in the absence of amyloid plaques and neurofibrillary tangles, suggesting the presence of oligomeric $\mathrm{A} \beta_{1-42}$ early in the progression of AD (Funato et al., 1999; Lue et al., 1999; McLean et al., 1999; Walsh et al., 2000; Dahlgren et al., 2002; Gong et al., 2003). Our findings of BDNF downregulation by oligomeric $\mathrm{A} \beta_{1-42}$ support the growing literature suggesting oligomeric $\mathrm{A} \beta_{1-42}$ is the first neurotoxic insult in $\mathrm{AD}$. Together with our recent findings of decreased $\mathrm{BDNF}$ in prodromal AD subjects (Peng et al., 2005), we propose that oligomeric amyloid-induced downregulation of BDNF in the brain is one of the primary and earliest mechanisms of neurodegeneration in $\mathrm{AD}$.

It was previously unknown which species of $A \beta_{1-42}$ downregulates BDNF. Here, we demonstrate that oligomeric but not fibrillar $\mathrm{A} \beta_{1-42}$ significantly decreases BDNF mRNA levels in differentiated SY5Y cells. Furthermore, undifferentiated, amyloid-treated SY5Y cells do not downregulate $\mathrm{BDNF}$, consistent with previous reports that undifferentiated SY5Y cells are not responsive to $\mathrm{A} \beta$ (Lambert et al., 1994).

To confirm that the effects of amyloid administration on BDNF expression occur before any cytotoxic effects, we demonstrated the absence of $\mathrm{LDH}$ release and of caspase activation, a proapoptotic marker, in amyloid-treated RA-differentiated SY5Y cells during the time course of BDNF mRNA measurement. Our results are in agreement with recent data demonstrating that $\mathrm{A} \beta$ derived diffusible ligands (of similar molecular weight to our oligomeric amyloid) induce subtle mitochondrial changes, but not overt cell death, in human cortical neurons over a period of 1 week (Deshpande et al., 2006). Therefore, oligomeric amyloidinduced BDNF downregulation is not a result of cell death.

In our previous study, we reported BDNF transcripts I, II, and III were significantly decreased in the parietal cortex of $\mathrm{AD}$ compared with control subjects (Garzon et al., 2002). Recently, there has been a revision to both the human and the rodent BDNF genes with the discovery of an additional exon between exons II and III (Liu et al., 2005, 2006). The newly discovered exon is called exon III and the previous exons III and IV are renamed exons IV and $\mathrm{V}$, respectively. Based on this revision, our previous data show a significant decrease in human BDNF transcripts I, II, and IV in the parietal cortex of AD compared with control subjects. In this study, consistent with Alzheimer's subjects, RAdifferentiated SY5Y cells exposed to oligomeric $\mathrm{A} \beta_{1-42}$ exhibit significantly decreased transcript IV (Garzon et al., 2002). BDNF transcript IV is the most abundantly expressed transcript in SY5Y cells and in human cortical tissue, exhibiting a 2- to 16 -fold greater level of expression than the other transcripts (Table 2) and accounting 
for more than one-half of the total BDNF mRNA. Therefore, downregulation of transcript IV is likely the primary driver behind downregulation of total BDNF mRNA by $\mathrm{A} \beta_{1-42}$ in both SY5Y cells and in human cortical tissue.

In differentiated SY5Y cells, BDNF transcript $\mathrm{V}$ is decreased $54 \%$ by oligomeric $A \beta_{1-42}$. In human cortical tissue, BDNF transcript $\mathrm{V}$ showed a similar trend in AD subjects compared with controls, but the finding was not statistically significant $(p=$ 0.062) (Garzon et al., 2002). The discrepancy between these findings is likely a result of insufficient sample numbers in our human cortical tissue analysis, diminished accuracy based on our previous use of relative RT-PCR versus real-time RT-PCR in this study, and intersubject variability in the human cortical tissue samples.

Interestingly, in differentiated SY5Ys, oligomeric amyloid increases BDNF transcript I and does not change BDNF transcript II, whereas in $\mathrm{AD}$, transcripts I and II are both decreased. The discrepancy between amyloid-treated SY5Y cells and human AD cortical samples suggests that factor(s) other than $A \beta$ are responsible for BDNF transcript I and II downregulation in AD. BDNF transcripts III, VI, and VII are minor contributors to total BDNF mRNA levels; in SY5Y cells, they are expressed at levels below our standard curve ( $<40$ copies/50 ng total RNA) and at least 16-fold lower than transcript IV.

The effect of $\mathrm{A} \beta$ on LTP and memory is postulated to be mediated by inhibition of CREB phosphorylation. Activation of CREB by phosphorylation is essential for learning and memory (Silva et al., 1998; Tully, 1998); P-CREB levels are decreased in $\mathrm{AD}$ hippocampus (Yamamoto-Sasaki et al., 1999) and in $\mathrm{A} \beta$ treated rat primary cortical neurons (Tong et al., 2001). A $\beta$ reduces adenylate cyclase and protein kinase A (PKA) activity and hence P-CREB levels in hippocampal neurons (Vitolo et al., 2002). Consistent with the role of P-CREB as a transcription factor for activity-dependent regulation of BDNF transcript IV (Shieh et al., 1998; Tao et al., 1998; Tong et al., 2001, 2004) and with our results demonstrating oligomeric amyloid-specific downregulation of BDNF transcript IV, we find only oligomeric, not fibrillar amyloid decreases the levels of P-CREB in SY5Y cells. Our results suggest that decreased CREB phosphorylation induced by oligomeric $A \beta$ is responsible for downregulation of BDNF transcript IV in SY5Y cells and in AD.

BDNF is a well known mediator of LTP and memory. Transgenic mice with reduced BDNF levels exhibit defects in synaptic transmission, LTP, and memory tests that are rescued by exogenous BDNF administration (Korte et al., 1995; Patterson et al., 1996; Olofsdotter et al., 2000), and reduced BDNF protein levels are correlated with cognitive impairment in $\mathrm{MCI}$ and $\mathrm{AD}$ subjects (Peng et al., 2005). Therefore, we propose a mechanism for the effects of $\mathrm{A} \beta$ on cognitive and memory function in $\mathrm{AD}$, which is that oligomeric $A \beta$ inhibits adenylate cyclase activity and reduces PKA activation, reducing CREB phosphorylation and subsequent BDNF transcript IV expression. Because transcript IV represents over one-half of the total BDNF mRNA, this mechanism may explain reduced BDNF in both RA-differentiated SY5Y cells and in human neurons exposed to $A \beta$, and identifies BDNF downregulation as an underlying event in $\mathrm{AD}$. Furthermore, because oligomeric amyloid appears before plaque deposition and because $\mathrm{BDNF}$ reduction occurs early in the course of $\mathrm{AD}$ and is correlated with cognitive dysfunction, oligomeric amyloid may produce synaptic dysfunction and learning and memory deficits by downregulation of BDNF before the clinical onset of Alzheimer's disease.

\section{References}

Aoyama M, Asai K, Shishikura T, Kawamoto T, Miyachi T, Yokoi T, Togari H, Wada Y, Kato T, Nakagawara A (2001) Human neuroblastomas with unfavorable biologies express high levels of brain-derived neurotrophic factor mRNA and a variety of its variants. Cancer Lett 164:51-60.

Bramham CR, Messaoudi E (2005) BDNF function in adult synaptic plasticity: the synaptic consolidation hypothesis. Prog Neurobiol 76:99-125.

Chui DH, Tanahashi H, Ozawa K, Ikeda S, Checler F, Ueda O, Suzuki H, Araki W, Inoue H, Shirotani K, Takahashi K, Gallyas F, Tabira T (1999) Transgenic mice with Alzheimer presenilin 1 mutations show accelerated neurodegeneration without amyloid plaque formation. Nat Med 5:560-564.

Coleman PD, Yao PJ (2003) Synaptic slaughter in Alzheimer's disease. Neurobiol Aging 24:1023-1027.

Connor B, Young D, Yan Q, Faull RL, Synek B, Dragunow M (1997) Brainderived neurotrophic factor is reduced in Alzheimer's disease. Brain Res Mol Brain Res 49:71-81.

Cummings BJ, Cotman CW (1995) Image analysis of beta-amyloid load in Alzheimer's disease and relation to dementia severity. Lancet 346:1524-1528.

Dahlgren KN, Manelli AM, Stine Jr WB, Baker LK, Krafft GA, LaDu MJ (2002) Oligomeric and fibrillar species of amyloid-beta peptides differentially affect neuronal viability. J Biol Chem 277:32046-32053.

Datki Z, Papp R, Zadori D, Soos K, Fulop L, Juhasz A, Laskay G, Hetenyi C, Mihalik E, Zarandi M, Penke B (2004) In vitro model of neurotoxicity of Abeta 1-42 and neuroprotection by a pentapeptide: irreversible events during the first hour. Neurobiol Dis 17:507-515.

Deshpande A, Mina E, Glabe C, Busciglio J (2006) Different conformations of amyloid $\beta$ induce neurotoxicity by distinct mechanisms in human cortical neurons. J Neurosci 26:6011-6018.

Encinas M, Iglesias M, Liu Y, Wang H, Muhaisen A, Cena V, Gallego C, Comella JX (2000) Sequential treatment of SH-SY5Y cells with retinoic acid and brain-derived neurotrophic factor gives rise to fully differentiated, neurotrophic factor-dependent, human neuron-like cells. J Neurochem 75:991-1003.

Feng X, Jiang H, Baik JC, Edgar C, Eide FF (2001) BDNF dependence in neuroblastoma. J Neurosci Res 64:355-363.

Ferrer I, Marin C, Rey MJ, Ribalta T, Goutan E, Blanco R, Tolosa E, Marti E (1999) BDNF and full-length and truncated TrkB expression in Alzheimer disease. Implications in therapeutic strategies. J Neuropathol Exp Neurol 58:729-739.

Funato H, Enya M, Yoshimura M, Morishima-Kawashima M, Ihara Y (1999) Presence of sodium dodecyl sulfate-stable amyloid beta-protein dimers in the hippocampus CA1 not exhibiting neurofibrillary tangle formation. Am J Pathol 155:23-28.

Garzon D, Yu G, Fahnestock M (2002) A new brain-derived neurotrophic factor transcript and decrease in brain-derived neurotrophic factor transcripts 1, 2 and 3 in Alzheimer's disease parietal cortex. J Neurochem 82:1058-1064.

Geula C (1998) Abnormalities of neural circuitry in Alzheimer's disease: hippocampus and cortical cholinergic innervation. Neurology 51:S18-S29.

Glenner GG, Wong CW (1984) Alzheimer's disease: initial report of the purification and characterization of a novel cerebrovascular amyloid protein. Biochem Biophys Res Commun 120:885-890.

Gong Y, Chang L, Viola KL, Lacor PN, Lambert MP, Finch CE, Krafft GA, Klein WL (2003) Alzheimer's disease-affected brain: presence of oligomeric A beta ligands (ADDLs) suggests a molecular basis for reversible memory loss. Proc Natl Acad Sci USA 100:10417-10422.

Grundke-Iqbal I, Iqbal K, Tung YC, Quinlan M, Wisniewski HM, Binder LI (1986) Abnormal phosphorylation of the microtubule-associated protein tau (tau) in Alzheimer cytoskeletal pathology. Proc Natl Acad Sci USA 83:4913-4917.

Hock C, Heese K, Hulette C, Rosenberg C, Otten U (2000) Region-specific neurotrophin imbalances in Alzheimer disease: decreased levels of brainderived neurotrophic factor and increased levels of nerve growth factor in hippocampus and cortical areas. Arch Neurol 57:846-851.

Holsinger RM, Schnarr J, Henry P, Castelo VT, Fahnestock M (2000) Quantitation of BDNF mRNA in human parietal cortex by competitive reverse transcription-polymerase chain reaction: decreased levels in Alzheimer's disease. Brain Res Mol Brain Res 76:347-354.

Irizarry MC, Soriano F, McNamara M, Page KJ, Schenk D, Games D, Hyman 
BT (1997) A $\beta$ deposition is associated with neuropil changes, but not with overt neuronal loss in the human amyloid precursor protein V717F (PDAPP) transgenic mouse. J Neurosci 17:7053-7059.

Kaplan DR, Matsumoto K, Lucarelli E, Thiele CJ (1993) Induction of TrkB by retinoic acid mediates biologic responsiveness to BDNF and differentiation of human neuroblastoma cells. Eukaryotic Signal Transduction Group. Neuron 11:321-331.

Kokaia Z, Metsis M, Kokaia M, Bengzon J, Elmer E, Smith ML, Timmusk T, Siesjo BK, Persson H, Lindvall O (1994) Brain insults in rats induce increased expression of the BDNF gene through differential use of multiple promoters. Eur J Neurosci 6:587-596.

Korte M, Carroll P, Wolf E, Brem G, Thoenen H, Bonhoeffer T (1995) Hippocampal long-term potentiation is impaired in mice lacking brainderived neurotrophic factor. Proc Natl Acad Sci USA 92:8856-8860.

Lacor PN, Buniel MC, Chang L, Fernandez SJ, Gong Y, Viola KL, Lambert MP, Velasco PT, Bigio EH, Finch CE, Krafft GA, Klein WL (2004) Synaptic targeting by Alzheimer's-related amyloid $\beta$ oligomers. J Neurosci 24:10191-10200.

Lambert MP, Stevens G, Sabo S, Barber K, Wang G, Wade W, Krafft G, Snyder S, Holzman TF, Klein WL (1994) Beta/A4-evoked degeneration of differentiated SH-SY5Y human neuroblastoma cells. J Neurosci Res 39:377-385.

Lambert MP, Barlow AK, Chromy BA, Edwards C, Freed R, Liosatos M, Morgan TE, Rozovsky I, Trommer B, Viola KL, Wals P, Zhang C, Finch CE, Krafft GA, Klein WL (1998) Diffusible, nonfibrillar ligands derived from Abeta1-42 are potent central nervous system neurotoxins. Proc Natl Acad Sci USA 95:6448-6453.

Liu QR, Walther D, Drgon T, Polesskaya O, Lesnick TG, Strain KJ, de Andrade M, Bower JH, Maraganore DM, Uhl GR (2005) Human brain derived neurotrophic factor (BDNF) genes, splicing patterns, and assessments of associations with substance abuse and Parkinson's Disease. Am J Med Genet B Neuropsychiatr Genet 134:93-103.

Liu QR, Lu L, Zhu XG, Gong JP, Shaham Y, Uhl GR (2006) Rodent BDNF genes, novel promoters, novel splice variants, and regulation by cocaine. Brain Res 1067:1-12.

Lu B (2003) BDNF and activity-dependent synaptic modulation. Learn Mem 10:86-98.

Lue LF, Kuo YM, Roher AE, Brachova L, Shen Y, Sue L, Beach T, Kurth JH, Rydel RE, Rogers J (1999) Soluble amyloid beta peptide concentration as a predictor of synaptic change in Alzheimer's disease. Am J Pathol 155:853-862.

McAllister AK, Katz LC, Lo DC (1999) Neurotrophins and synaptic plasticity. Annu Rev Neurosci 22:295-318.

McLean CA, Cherny RA, Fraser FW, Fuller SJ, Smith MJ, Beyreuther K, Bush AI, Masters CL (1999) Soluble pool of Abeta amyloid as a determinant of severity of neurodegeneration in Alzheimer's disease. Ann Neurol 46:860-866.

Metsis M, Timmusk T, Arenas E, Persson H (1993) Differential usage of multiple brain-derived neurotrophic factor promoters in the rat brain following neuronal activation. Proc Natl Acad Sci USA 90:8802-8806.

Naslund J, Haroutunian V, Mohs R, Davis KL, Davies P, Greengard P, Buxbaum JD (2000) Correlation between elevated levels of amyloid betapeptide in the brain and cognitive decline. JAMA 283:1571-1577.

Ohara O, Gahara Y, Teraoka H, Kitamura T (1992) A rat brain-derived neurotrophic factor-encoding gene generates multiple transcripts through alternative use of $5^{\prime}$ exons and polyadenylation sites. Gene 121:383-386.

Olofsdotter K, Lindvall O, Asztely F (2000) Increased synaptic inhibition in dentate gyrus of mice with reduced levels of endogenous brain-derived neurotrophic factor. Neuroscience 101:531-539.

Pahlman S, Ruusala AI, Abrahamsson L, Mattsson ME, Esscher T (1984) Retinoic acid-induced differentiation of cultured human neuroblastoma cells: a comparison with phorbolester-induced differentiation. Cell Differ 14:135-144.

Pahlman S, Mamaeva S, Meyerson G, Mattsson ME, Bjelfman C, Ortoft E, Hammerling U (1990) Human neuroblastoma cells in culture: a model for neuronal cell differentiation and function. Acta Physiol Scand Suppl 592:25-37.

Patterson SL, Abel T, Deuel TA, Martin KC, Rose JC, Kandel ER (1996) Recombinant BDNF rescues deficits in basal synaptic transmission and hippocampal LTP in BDNF knockout mice. Neuron 16:1137-1145.

Peng S, Wuu J, Mufson EJ, Fahnestock M (2005) Precursor form of brainderived neurotrophic factor and mature brain-derived neurotrophic factor are decreased in the pre-clinical stages of Alzheimer's disease. J Neurochem 93:1412-1421.

Phillips HS, Hains JM, Armanini M, Laramee GR, Johnson SA, Winslow JW (1991) BDNF mRNA is decreased in the hippocampus of individuals with Alzheimer's disease. Neuron 7:695-702.

Selkoe DJ (1994) Alzheimer's disease: a central role for amyloid. J Neuropathol Exp Neurol 53:438-447.

Shieh PB, Hu SC, Bobb K, Timmusk T, Ghosh A (1998) Identification of a signaling pathway involved in calcium regulation of BDNF expression. Neuron 20:727-740.

Silva AJ, Kogan JH, Frankland PW, Kida S (1998) CREB and memory. Annu Rev Neurosci 21:127-148.

Stine Jr WB, Dahlgren KN, Krafft GA, LaDu MJ (2003) In vitro characterization of conditions for amyloid-beta peptide oligomerization and fibrillogenesis. J Biol Chem 278:11612-11622.

Tao X, Finkbeiner S, Arnold DB, Shaywitz AJ, Greenberg ME (1998) $\mathrm{Ca}^{2+}$ influx regulates BDNF transcription by a CREB family transcription factor-dependent mechanism. Neuron 20:709-726.

Timmusk T, Lendahl U, Funakoshi H, Arenas E, Persson H, Metsis M (1995) Identification of brain-derived neurotrophic factor promoter regions mediating tissue-specific, axotomy-, and neuronal activity-induced expression in transgenic mice. J Cell Biol 128:185-199.

Tong L, Thornton PL, Balazs R, Cotman CW (2001) Beta-amyloid-(1-42) impairs activity-dependent cAMP-response element-binding protein signaling in neurons at concentrations in which cell survival Is not compromised. J Biol Chem 276:17301-17306.

Tong L, Balazs R, Thornton PL, Cotman CW (2004) Beta-amyloid peptide at sublethal concentrations downregulates brain-derived neurotrophic factor functions in cultured cortical neurons. J Neurosci 24:6799-6809.

Tully T (1998) Toward a molecular biology of memory: the light's coming on! Nat Neurosci 1:543-545.

Vitolo OV, Sant'Angelo A, Costanzo V, Battaglia F, Arancio O, Shelanski M (2002) Amyloid beta-peptide inhibition of the PKA/CREB pathway and long-term potentiation: reversibility by drugs that enhance cAMP signaling. Proc Natl Acad Sci USA 99:13217-13221.

Walsh DM, Tseng BP, Rydel RE, Podlisny MB, Selkoe DJ (2000) The oligomerization of amyloid beta-protein begins intracellularly in cells derived from human brain. Biochemistry 39:10831-10839.

Walsh DM, Klyubin I, Fadeeva JV, Cullen WK, Anwyl R, Wolfe MS, Rowan MJ, Selkoe DJ (2002) Naturally secreted oligomers of amyloid beta protein potently inhibit hippocampal long-term potentiation in vivo. Nature 416:535-539.

Wu ZL, Ciallella JR, Flood DG, O’kane TM, Bozyczko-Coyne D, Savage MJ (2006) Comparative analysis of cortical gene expression in mouse models of Alzheimer's disease. Neurobiol Aging 27:377-386.

Yamamoto-Sasaki M, Ozawa H, Saito T, Rosler M, Riederer P (1999) Impaired phosphorylation of cyclic AMP response element binding protein in the hippocampus of dementia of the Alzheimer type. Brain Res 824:300-303.

Yuan J, Yankner BA (2000) Apoptosis in the nervous system. Nature 407: 802-809. 